\title{
Factors affecting the long-term variability of bronchial responsiveness in an adult general practice population
}

\author{
C.J. Trigg*, M. Tooley**, M.F. D'Souza**, M.J. Herdman*, J.M. Thomas*, R.J. Davies*
}

Factors affecting the long-term variability of bronchial responsiveness in an adult general practice population. C.J. Trigg, M. Tooley, M.F. D'Souza, M.J. Herdman, J.M. Thomas, R.J. Davies. CERS Journals Ltd 1994.

ABSTRACT: There have been few longitudinal studies of bronchial responsiveness. We wanted to assess the long-term variability and associations of bronchial responsiveness in the general population.

Spirometry, bronchial provocation tests, skin-prick tests for allergy, and respiratory symptom questionnaires were repeated every 4 months, for 2 years (August 1987-August 1989), in 122 volunteers recruited from a cross-sectional survey of population. Provocation dose producing a $20 \%$ fall in forced expiratory volume in one second $\left(\mathrm{PD}_{20} \mathrm{FEV}_{1}\right)$ and dose-response slope $(\mathrm{SL})$, which gives values for methacholine responsiveness, were measured in all subjects.

SL correlated well with $\mathrm{PD}_{20} \mathrm{FEV}_{1}$ but repeatability was impaired in those subjects with unmeasurably high $\mathrm{PD}_{20} \mathrm{FEV}_{1}$. The $95 \%$ range for repeatability of $\mathrm{PD}_{20} \mathrm{FEV}_{1}$ was \pm 3.12 doubling doses and $\pm \mathbf{4 . 5 2}$ doubling slopes for SL. Bronchial responsiveness increased in those with self-reported colds and reduced $F_{E V}$ in winter 1987-1988, and in males in winter 1988-1989. Bronchial responsiveness increased during the summer (June-August) of both years, significantly in year 1 .

We conclude that bronchial responsiveness showed minor seasonal variability and that colds were the strongest predictors of increased bronchial responsiveness over the 2 yr period.

Eur Respir J., 1994, 7, 703-709.

\begin{abstract}
*Academic Dept of Respiratory Medicine, St Bartholomew's Hospital, London, UK. Unit of General Practice, National Heart and Lung Institute, The Canbury Medical Centre, Kingston, UK.
\end{abstract}

Correspondence: C.J. Trigg Academic Dept of Respiratory Medicine St Bartholomew's Hospital London

UK

Keywords: Asthma

bronchial responsiveness

methacholine challenge

Received: December 221992

Accepted after revision December 311993
The prevalence of asthma in the population is uncertain, owing to the absence of "gold standard" diagnostic criteria for the disease. Initial observations suggested that airflow limitation in response to cholinergic agents and histamine was specific to asthma $[1,2]$. Such bronchial hyperresponsiveness is now known to occur in a number of other respiratory diseases [3-5]. Community surveys have also shown a high prevalence in apparently asymptomatic individuals [6], and there appears to be an inherited component [7]. In keeping with a multifactorial aetiology, bronchial responsiveness follows a unimodal distribution in the population [8, 9].

The significance of bronchial hyperresponsiveness as an isolated finding is uncertain. Our previous crosssectional general practice survey showed associations with symptoms of wheezing, recent attacks of rhinitis, diurnal variation in peak expiratory flow rate (PEFR), atopic status, resting forced expiratory volume in one second $\left(\mathrm{FEV}_{1}\right)$ histamine skin weal area, smoking and female gender [9].

There have been few longitudinal studies of bronchial hyperresponsiveness [10]. Clough et al. [11] found no correlation between exacerbations of asthma symptoms and changes in bronchial responsiveness over one year. Lung function decline has been shown to be accelerated in asthmatics [12], and in patients with bronchial hyperresponsiveness and chronic airflow limitation [13]. It may also be accelerated in nonasthmatics with bronchial hyperresponsiveness, although a recent study was not strictly prospective [14].

BRITTON et al. [15] showed that bronchial responsiveness to histamine increased in a sample of patients from a community-based adult population during July and September, and this increase correlated with mean allergen skin weal area and airflow obstruction.

The purpose of this study was to follow subjects from a normal population for 2 yrs in order to investigate the variability of bronchial responsiveness in the population in relation to symptoms, atopy, cigarette smoking and season. We used methacholine, which is tolerated at higher dose than histamine [16], in order to characterize a wider range of bronchial responsiveness than in previous studies [15].

\section{Subjects and methods}

\section{Preceding cross-sectional survey}

Between 1984 and 1986, 366 subjects aged 18-75 yrs were recruited as a representative sample of the list of a general practice. The method of recruitment has been 
described previously, but was essentially a systematic 1:12 sample drawn from the practice age:sex register [9]. All subjects had completed a questionnaire on respiratory symptoms. Spirometry, bronchial provocation testing with methacholine, and skin-prick testing to six common allergens had been performed in 318 individuals.

\section{Selection of participants for follow-up study (fig. 1)}

In the above study, $23 \%$ of the patients $(n=74)$ recorded a provocation dose $\left(\mathrm{PD}_{20} \mathrm{FEV}_{1}\right)$ of methacholine $<11$ $\mu \mathrm{mol}$ and were regarded as demonstrating bronchial hyperresponsiveness, based on the results of a previous study of asthmatics [17]. All were invited to take part in the follow-up study and 41 agreed. A further 98 patients recorded $\mathrm{PD}_{20} \mathrm{FEV}_{1}$ in the range $>11-247 \mu \mathrm{mol}$, the maximum dose; of these, 40 agreed to take part. A further 41 patients were selected from the database as a control group. These patients were those in whom a $20 \%$ fall in $\mathrm{FEV}_{1}$ was not reached at the maximum dose of methacholine. They were matched as closely as possible to those with bronchial hyperresponsiveness for age, sex, resting $\mathrm{FEV}_{1}$, smoking history and atopic status, in order to minimize the effect of other variables associated with bronchial hyperresponsiveness. Current smokers were those who had smoked tobacco in the preceding month. Ex-smokers were those who had smoked tobacco up to a month previously. A total of 122 subjects agreed to participate in the follow-up study. The study was approved by the Ethics Committee of Kingston Health Authority and signed informed consent was obtained from each patient.

\section{Subject characteristics (table 1)}

The low proportion of men reflects the original 2.4:1 preponderance of women among those with bronchial hyperresponsiveness. Subject characteristics only differed significantly from the original population sample
Table 1. - Subject characteristics

\begin{tabular}{|c|c|c|c|}
\hline & \multicolumn{3}{|c|}{$\mathrm{PD}_{20} \mathrm{FEV}_{1} \mu \mathrm{mol}$} \\
\hline & $\begin{array}{c}<11 \\
\text { Group } 1\end{array}$ & $\begin{array}{c}11-247 \\
\text { Group } 2\end{array}$ & $\begin{array}{c}>247 \\
\text { Group } 3\end{array}$ \\
\hline Subjects $\mathrm{n}$ & 41 & 40 & 41 \\
\hline Age $\mathrm{yrs}^{\dagger}$ & $43 \pm 5$ & $45 \pm 4$ & $41 \pm 4$ \\
\hline Age range yrs & $21-71$ & $24-69$ & $19-67$ \\
\hline Sex ratio $M / F$ & $10 / 31$ & $14 / 26$ & $10 / 31$ \\
\hline $\mathrm{FEV}_{1} \%$ pred $^{\dagger}$ & $96 \pm 4$ & $99 \pm 6$ & $103 \pm 5 *$ \\
\hline $\begin{array}{l}\mathrm{FEV}_{1} \% \text { pred }{ }^{\dagger} \\
\text { Smoking habit }\end{array}$ & $70-119$ & $72-158$ & $70-129$ \\
\hline Current \% & 39 & 37 & $17 *$ \\
\hline Ex-smoker $\%$ & 32 & 24 & 26 \\
\hline Nonsmoker $\%$ & 29 & 39 & 57 \\
\hline Atopic \% & 53 & 38 & $29 *$ \\
\hline
\end{tabular}

: mean $\pm 95 \%$ confidence interval; ${ }^{\dagger}$ : range. \% pred: percentage predicted for age and height. *: significant difference $\left(\mathrm{p}<0.05\right.$ between Group 1 and 3 (two sample t-test for $\mathrm{FEV}_{1}$, Chi-squared test for smoking status and $\%$ atopic). $\mathrm{FEV}_{1}$ : forced expiratory volume in one second; $\mathrm{PD}_{20} \mathrm{FEV}_{1}$ : provoca-

for gender among those with $\mathrm{PD}_{20} \mathrm{FEV}_{1}>247 \mu \mathrm{mol}$, due to matching for gender to the group with bronchial hyperresponsiveness. Bronchial hyperresponsiveness was associated with low resting $\mathrm{FEV}_{1}$ atopy and smoking.

Only 26 subjects had bronchial hyperresponsiveness at the first test of the follow-up study, 18-36 months after the original survey. They were significantly older (mean age $\pm 95 \%$ confidence interval (CI) $51 \pm 6$ yrs) than the remainder of the subjects $(44 \pm 2 \mathrm{yrs})(\mathrm{p}<0.05)$.

There were some differences between the males and females. Resting $\mathrm{FEV}_{1}$, was significantly higher in men than women, as would be expected $(\mathrm{p}<0.001)$. Percentage predicted $\mathrm{FEV}_{1}$ was significantly lower in men $(\mathrm{p}=0.049)$, because more were smokers (42 vs $25 \%$ of the women; Chi-squared 5.99; $\mathrm{p}=0.05 ; 2$ degrees of freedom). Inclusion of smoking in a linear regression of resting $\mathrm{FEV}_{1}$ on

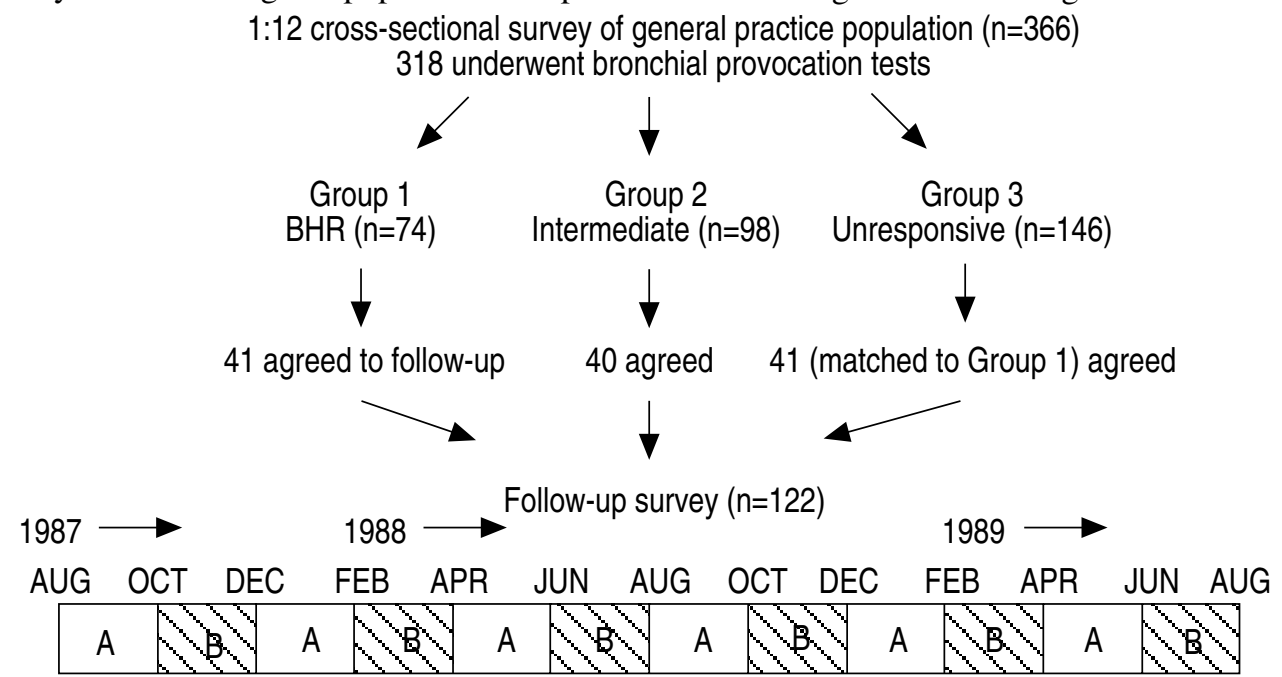

Fig. 1. - Scheme demonstrating the process of subject selection for the study and the study design. BHR: bronchial hyperresponsiveness. All tests performed four monthly for 2 yrs. Patients tested in either Block A or Block B of each 4 month period; see Method section "Study Design". Tests included: methacholine bronchial provocation tests, allergy skin-prick tests, and questionnaire. 
gender showed that the association was dependent on smoking. The mean reduction in $\mathrm{FEV}_{1}$ was $8.4 \%$ (SD $3.6 \%$ ) in those who had ever smoked.

Twenty seven subjects withdrew from the study. Four complained of adverse events after the first attendance: one asthmatic woman reported a deterioration in symptom control for a week after bronchial provocation tests; one woman complained of chest pains; one man had a persistent cough for 1-2 weeks after the tests; and one man said that his eczema had been exacerbated by the tests. Seven subjects moved from the district, and a further 16 subjects were unable to continue to give their time for the study. There were no significant differences in the withdrawal group compared to the remainder, although withdrawal was greater among smokers, females, atopics and those with bronchial hyperresponsiveness. Ninety five subjects completed the $2 \mathrm{yr}$ follow-up study.

\section{Methods}

Bronchial provocation testing with methacholine. $\mathrm{FEV}_{1}$ was recorded using a dry bellows spirometer (Vitalograph Ltd, Buckingham, UK) as the best of three reproducible attempts. Where resting $\mathrm{FEV}_{1}$ was within $70 \%$ of predicted value for age and height [18], inhalation challenge proceeded, using a standard tidal breathing method, which has been described and validated previously [17]. A DeVilbiss 646 nebulizer (DeVilbiss Health Care Ltd, Poole, UK) driven by air at $6 l \cdot \mathrm{min}^{-1}$ was used. The aerosol was inhaled tidally for 2 min using a mouthpiece and noseclip. Phenol saline diluent $(0.5 \% \mathrm{NaCl}, 0.275 \%$ $\mathrm{NaHCO}_{3}, 0.4 \%$ phenol) was inhaled as a control. $\mathrm{FEV}_{1}$ was recorded as the best of two reproducible attempts 30, 90 and $180 \mathrm{~min}$ after inhalation. This was followed by doubling concentrations of methacholine (acetyl-betamethacholine chloride, Sigma Chemical Co. Ltd, Poole, UK) from 0.03 to $32 \mathrm{mg} \cdot \mathrm{ml}^{-1}$ at $5 \mathrm{~min}$ intervals, provided that $\mathrm{FEV}_{1}$ did not fall by more than $15 \%$ following control. Challenge was terminated at $>20 \%$ fall in $\mathrm{FEV}_{1}$ from the post-control value, or at the maximum concentration. Two hundred micrograms of salbutamol was then administered by metered dose inhaler. Nebulizer output was determined by weighing before and after operation with $5 \mathrm{ml}$ of phenol saline in the chamber on 20 occasions. The $\mathrm{PD}_{20} \mathrm{FEV}_{1}$ was calculated by linear interpolation of the last two points on the logarithmic dose response curve as the cumulative dose of methacholine required to provoke a $20 \%$ fall in $\mathrm{FEV}_{1}$. The doseresponse slope (SL) was also calculated as the maximum percentage fall in $\mathrm{FEV}_{1}$ divided by the cumulative dose of methacholine administered [19]. This parameter can be calculated for individuals with less than $20 \%$ change in $\mathrm{FEV}_{1}$.

Skin prick tests (Bencard, Brentford, UK): House dust $(150 \% \mathrm{w} / \mathrm{v})$, Dermatophagoides pteronyssinus $(1.2 \%$ $\mathrm{w} / \mathrm{v}), \mathrm{B} 2$ grass pollen $(2.5 \% \mathrm{w} / \mathrm{v})$, Aspergillus fumigatus $(5 \% \mathrm{w} / \mathrm{v})$, cat fur $(150 \% \mathrm{w} / \mathrm{v}), \operatorname{dog}$ hair $(150 \% \mathrm{w} / \mathrm{v})$ histamine $\left(10 \mathrm{mg} \cdot \mathrm{ml}^{-1}\right)$, and normal saline $(0.9 \% \mathrm{w} / \mathrm{v})$ as control. Skin tests were regarded as positive if the mean weal diameter was at least $1 \mathrm{~mm}$ greater than that of the saline control, as in our previous study [9]. Atopy was defined by one or more positive skin-prick tests.

A written questionnaire. A written questionnaire concerning respiratory symptoms was completed for the preceding 6 weeks, a time period in which changes in bronchial responsiveness may persist after respiratory tract infection [5]. Questions were obtained from a previously validated computer administered questionnaire based on the Medical Research Council (MRC) Respiratory Symptoms Questionnaire [20]. Subjects were also asked to keep a diary card, on which they recorded the number of days on which they had experienced respiratory symptoms during each month. Categories included asthma; wheezing; bronchitis; colds; cough; early morning or night-time cough, wheeze or breathlessness; rhinitis; sneezing, nasal blockage, runny nose. Peak expiratory flow monitoring was not requested, as compliance is often poor and would deteriorate over 2 yrs.

\section{Study design}

Subjects were seen on six occasions at the medical centre where all tests were performed at 4 month intervals (fig. 1). Tests commenced on 15th August 1987, patients being seen between 15th August and 14th December 1987 . Tests were repeated between 15 th December 1987 and 14th April 1988; 15th April and 14th August 1988; 15th August and 14th December 1988; 15th December 1988 and 14th April 1989; and 15th April and 14th August 1989. Subjects were randomly allocated to two groups: Block A comprising those tested in the first 2 months, and Block B those tested in the second 2 months, respectively, of each 4 month period. Block $A$ indicates subjects studied between August 15th and October 14th; December 15th and February 14th; and April 15th and June 14th. Block B indicates patients studied between October 15th and December 14th; February 15th and April 14th; and June 15th and August 14th, of each year.

\section{Analysis of results}

Chi-squared tests were used to compare categorical variables (atopy, bronchial hyperresponsiveness, gender, respiratory symptoms and smoking). Age and $\mathrm{FEV}_{1}$ were compared using a two sample t-test, following a normal probability plot and the Shapiro-Wilk test.

$\mathrm{PD}_{20} \mathrm{FEV}_{1}$ and SL values were logarithmically transformed. A constant of 0.04 was added to SL in all cases before logarithmic transformation to accommodate the data of three individuals with a rise in $\mathrm{FEV}_{1}$ during challenge. (Negative values cannot be log-transformed). Variability of $\mathrm{PD}_{20} \mathrm{FEV}_{1}$ was assessed by two-way analysis of variance (ANOVA) [21] for individuals in whom methacholine provoked a $20 \%$ fall in $\mathrm{FEV}_{1}$ at every visit. For SL, values were available for all cases. Neither $\mathrm{PD}_{20} \mathrm{FEV}_{1}$ nor SL values were assigned for patients who responded with $>15 \%$ fall in $\mathrm{FEV}_{1}$ on inhalation of control solution, as a saline response cannot be assumed to represent heightened methacholine responsiveness. Arbitrary methacholine $\mathrm{PD}_{20} \mathrm{FEV}_{1}$ or SL values appeared as outliers from the 
normal distribution of the remaining data. Changes in $\mathrm{PD}_{20} \mathrm{FEV}_{1}$ and SL were calculated in terms of doubling doses of methacholine or doubling slope, respectively, (logarithmic value divided by $\log _{10} 2$ ). These values are more readily interpretable in confidence intervals than logarithmic dose or slope.

The intraclass correlation coefficient (ICCC) was calculated for $\mathrm{PD}_{20} \mathrm{FEV}_{1}$ and SL from a one-way ANOVA [22]. The repeatability of $\mathrm{PD}_{20} \mathrm{FEV}_{1}$ and SL was assessed by two-way ANOVA. A 95\% confidence interval and 95\% range for the difference between the mean values of any two tests were calculated, using the error mean square from two-way ANOVA [22].

Stepwise multiple linear regression (SMLR) [23] and repeated measures analysis of variance (RMAOV) [24] (General linear models program, SAS statistical software inc., USA) were used to determine the associations of change in bronchial responsiveness (logarithmically transformed) over time, with age, resting $\mathrm{FEV}_{1}$, atopy, cigarette smoking, colds, and month of test. Each variable was classified into two categories. Age was divided by the median (46 yrs). Resting $\mathrm{FEV}_{1}$ was divided at $90 \%$ predicted, on the basis that use of the median of $100 \%$ would be relatively insensitive to the influence of low $\mathrm{FEV}_{1}$, whereas a lower cut-off point would include very few cases. Atopics and smokers were defined as in the Methods section. Colds were defined by a positive response to the question "Have you had a cold in the last six weeks?" Virological data were not collected. The influence of month of test was assessed by dividing each 4 month period into 2 month blocks, as subjects studied early in each four month period would be subject to different environmental influences than those studied late.

\section{Results}

Variability of bronchial responsiveness

Twenty six subjects had bronchial hyperresponsiveness $\left(\mathrm{PD}_{20} \mathrm{FEV}_{1}<11 \mu \mathrm{mol}\right), 54$ had intermediate bronchial responsiveness $\left(\mathrm{PD}_{20} \mathrm{FEV}_{1}\right.$ in the range $\left.>11-247 \mu \mathrm{mol}\right)$ and 42 had unmeasurably high $\operatorname{PD}_{20} \mathrm{FEV}_{1}(>247 \mu \mathrm{mol})$ at the first test of the follow-up survey. Forty five patients recorded a measurable $\mathrm{PD}_{20} \mathrm{FEV}_{1}$ at each attendance in the first year, and 40 in the second year. Only 27 subjects recorded a measurable $\mathrm{PD}_{20} \mathrm{FEV}_{1}$ at every attendance over 2 yrs. In these selected subjects, two-way ANOVA showed no significant seasonal changes in bronchial responsiveness. The ICCC for repeatability was 0.48 (95\% CI $0.34-0.65)$. The $95 \% \mathrm{CI}$ for variability of $\mathrm{PD}_{20} \mathrm{FEV}_{1}$ between any two time periods was \pm 0.61 doubling doses (DD) of methacholine, with a $95 \%$ range of $\pm 3.12 \mathrm{DD}$ (two-way ANOVA: error mean square 0.109, $\mathrm{F}_{5,130}=1.03$ ).

In comparison, analysis of SL for 67 complete data sets showed no significant seasonal changes. SL was lognormally distributed. ICCC was 0.75 (95\% CI 0.67-0.82). $95 \%$ CI for variability was \pm 0.34 doubling slopes (DS), with a $95 \%$ range of $\pm 4.52 \mathrm{DS}$. $\log _{10} \mathrm{PD}_{20} \mathrm{FEV}_{1}$ and $\log _{10}$ SL showed a strong negative correlation ( $\mathrm{r}=-0.953)$ (fig. 2 ). The $95 \%$ CI for paired readings was $\pm 0.49 \mathrm{DS}$ for

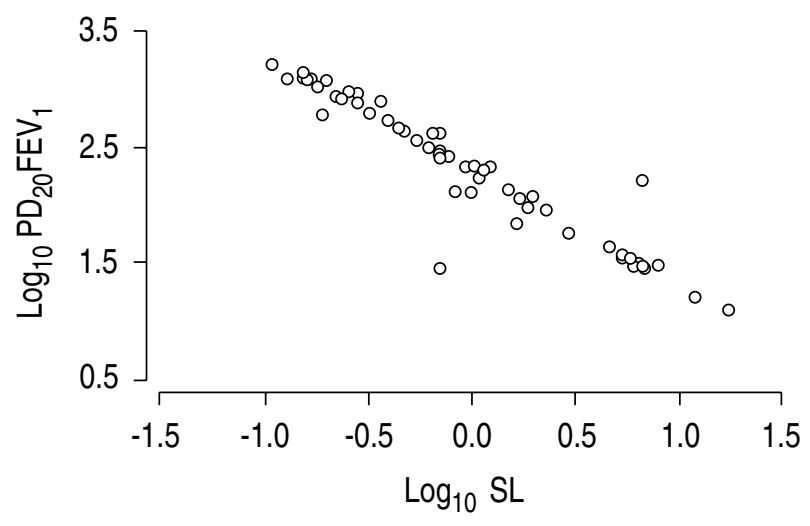

Fig. 2. - Inverse relationship between $\log _{10} \mathrm{PD}_{20} \mathrm{FEV}_{1}$ and $\log _{10} \mathrm{SL}$. (Measurable range of $\mathrm{PD}_{20} \mathrm{FEV}_{1}$ only). $\mathrm{PD}_{20} \mathrm{FEV}_{1}$ : provocative dose producing a $20 \%$ fall in forced expiratory volume in one second; SL: dose response slope, calculated as maximum percentage fall in $\mathrm{FEV}_{1}$ divided by cumulative dose of methacholine delivered.

those with corresponding $\mathrm{PD}_{20} \mathrm{FEV}_{1}$ values compared to \pm 0.92 DS for those without, indicating impaired repeatability in individuals with minimal responsiveness.

Results for each year were analysed separately, to use more $\mathrm{PD}_{20} \mathrm{FEV}_{1}$ data. Again, no significant seasonal variation was shown. The ICCC was 0.56 (95\% CI 0.45-0.70) for the first year, and 0.68 (95\% CI $0.58-0.78)$ for the second year. The $95 \%$ CI was \pm 0.52 DD for year 1 , and $\pm 0.43 \mathrm{DD}$ for year 2 , with $95 \%$ ranges of $\pm 3.71 \mathrm{DD}$ and \pm 3.43 DD, respectively, (two-way ANOVA year 1: error mean square $0.171, \mathrm{~F}_{2.88}=0.39$; and year 2 : error mean square $0.083, \mathrm{~F}_{278}=1.71$ ).

Factors contributing to variability in bronchial responsiveness

Each year's data were analysed separately to use the maximum available data (37 complete $\mathrm{PD}_{20} \mathrm{FEV}_{1}$ and 72 complete SL data sets each year). The numbers are slightly reduced by exclusion of individuals who moved from block A to block B because of repeated failure to attend.

SMLR for both $\mathrm{PD}_{20} \mathrm{FEV}_{1}$ and SL (fig. 3) showed that low age and low resting $\mathrm{FEV}_{1}$ were independently associated with increasing bronchial responsiveness between

\begin{tabular}{|c|c|c|c|c|c|c|c|}
\hline AUG & OCT & & & FEB & APR & & $A \cup G$ \\
\hline A & & $B$ & $A$ & $B$ & & $A$ & \\
\hline
\end{tabular}

Year 1

\begin{tabular}{|c|c|c|c|c|c|}
\hline Nil & Nil & $\begin{array}{l}\mathrm{FEV}_{1} \text {, age } \\
\text { cold (SL) }\end{array}$ & Cold & Nil & Nil \\
\hline \multicolumn{6}{|l|}{ Year 2} \\
\hline Nil & Nil & Nil & Male (SL) & $\begin{array}{l}\text { Atopy(-) } \\
\text { (SL) }\end{array}$ & Nil \\
\hline
\end{tabular}

Fig. 3. - Summary of significant associations of variability of bronchial responsiveness on stepwise multiple linear regression. Only independently significant $(\mathrm{p}<0.05)$ factors included. $(\mathrm{SL})$ : factor only associated with SL variability and not with $\mathrm{PD}_{20} \mathrm{FEV}_{1}$ variability; (-) negative association. For abbreviations see legend to figure 2 . 
December 1987 and April 1988, predominantly in those studied in Block A $(\mathrm{p}<0.05)$. Additionally, self-reported colds at this time were associated with increased bronchial responsiveness $(\mathrm{p}<0.01)$. The effect of colds was predominant in Block $\mathrm{B}$ for $\mathrm{PD}_{20} \mathrm{FEV}_{1}$ and block $\mathrm{A}$ for SL. SMLR for SL showed a reduction in bronchial responsiveness in April-June 1988 (Block A) associated with grass pollen (GP) skin-prick test positivity $(\mathrm{p}<0.01)$, contrary to the expected increase with the pollen season. The effect of house dust mite (HDM) positivity was only significant in association with GP positivity, and had the opposite influence $(\mathrm{p}=0.05)$. Few subjects had positive tests during this time period (8 GP and $10 \mathrm{HDM}$ ). Although 35 of the 122 volunteers had positive HDM and 21 individuals had positive GP skin-prick tests at recruitment, numbers were subsequently reduced by withdrawals, non-attendance and saline responses. In year 2, SL was significantly reduced in atopic individuals between April-June 1989 (Block A). SL was also significantly reduced between February-April 1989 (Block B) in atopics (positive grass pollen, dog and house dust skin-prick tests). Atopy was not independently significant on SMLR, being outweighed by the effect of male gender, which was associated with reduced bronchial responsiveness between February-April 1989. The findings are summarized in figure 3 .

RMAOV showed that colds and low $\mathrm{FEV}_{1}$ were significantly associated with reduced $\mathrm{PD}_{20} \mathrm{FEV}_{1}$ in the first year of the study, the effect being limited to winter 1987-1988. For SL, colds were only associated with a trend towards increased responsiveness at this time. Tables 2 and 3 show the interaction of time of test with specific factors. In table $2 \mathrm{~A}$, the effect of $\mathrm{FEV}_{1}$ on $\mathrm{PD}_{20} \mathrm{FEV}_{1}$ shows a significant association with time (time $\left.\times \mathrm{FEV}_{1}\right)$, and this effect is shown to be accounting for variability between Period 1 and $2(\mathrm{p}=0.008)$ but not between period 2 and 3. Likewise, self-reported colds are associated with $\mathrm{PD}_{20} \mathrm{FEV}_{1}$ variability between Period 1 and 2 . SL was also significantly influenced by male gender in

Table 2. - Summary of significant factors entered into repeated measures analysis of variance of $\mathrm{PD}_{20} \mathrm{FEV}_{1}$

\begin{tabular}{lll}
\hline & F-statistic & p-value \\
\hline $\begin{array}{l}\text { A. Year 1 } \\
\text { Time } \times \text { FEV }\end{array}$ & $\mathrm{F}_{2,68}=5.23$ & 0.008 \\
Period 1-2 & $\mathrm{F}_{1,34}=7.92$ & 0.008 \\
Period 2-3 & $\mathrm{F}_{1,34}=0.06$ & $0.816(\mathrm{NS})$ \\
Timexcold* & $\mathrm{F}_{2,68}=4.23$ & 0.021 \\
Period 1-2 & $\mathrm{F}_{1,34}=8.10$ & 0.008 \\
Period 2-3 & $\mathrm{F}_{1,34}=1.80$ & $0.188(\mathrm{NS})$ \\
B. Year 2 & & \\
Time×block* & $\mathrm{F}_{2,68}=4.41$ & 0.019 \\
Period 4-5 & $\mathrm{F}_{1,34}=0.82$ & 0.372 \\
Period 5-6 & $\mathrm{F}_{1,34}=3.45$ & 0.071 \\
\hline
\end{tabular}

Cold: self-reported cold within six weeks of tests during period 2. Block A and B: first and second two months, respectively, of each four month time period. "Time" refers to the effect of four month time period during which tests were performed. Ns: nonsignificant. For further abbreviations see legend to table 1 .
Table 3. - Summary of repeated measures analysis of variance for dose-response-slope

\begin{tabular}{lll}
\hline & $\mathrm{F}_{\text {-statistic }}$ & p-value \\
\hline Year 1 & $\mathrm{F}_{2,140}=2.94$ & \\
Time $\times$ block & $\mathrm{F}_{1,70}=0.02$ & 0.060 \\
Period 2-1 & $\mathrm{F}_{1,70}=5.29$ & 0.894 \\
Period 3-2 & $\mathrm{F}_{2,140}=3.74$ & 0.025 \\
Time $\times$ FEV & $\mathrm{F}_{1,70}=5.34$ & 0.026 \\
Period 2-1 & $\mathrm{F}_{1,70}=0.01$ & 0.023 \\
Period 3-2 & $\mathrm{F}_{2,140}=2.44$ & 0.935 \\
Timexcold & $\mathrm{F}_{1,70}=4.05$ & 0.092 \\
Period 2-1 & $\mathrm{F}_{1,70}=3.06$ & 0.048 \\
Period 3-2 & & 0.085 \\
Year 2 & $\mathrm{F}_{2,138}=3.04$ & \\
Time $\times$ block & $\mathrm{F}_{1,69}=1.58$ & 0.052 \\
Period 5-4 & $\mathrm{F}_{1,69}=1.28$ & 0.213 \\
Period 6-5 & $\mathrm{F}_{2,138}=5.15$ & 0.261 \\
Time $\times$ gender & $\mathrm{F}_{1,69}=9.88$ & 0.007 \\
Period 5-4 & $\mathrm{F}_{1,69}=4.40$ & 0.003 \\
Period 6-5 & . & 0.040 \\
\hline
\end{tabular}

Cold: self-reported cold within six weeks of tests during period 2. Block A and B: first and second two month block, respectively, during each four month period. "Time" refers to the effect of four month time period during which test were performed. For abbreviations see legend to table 1.
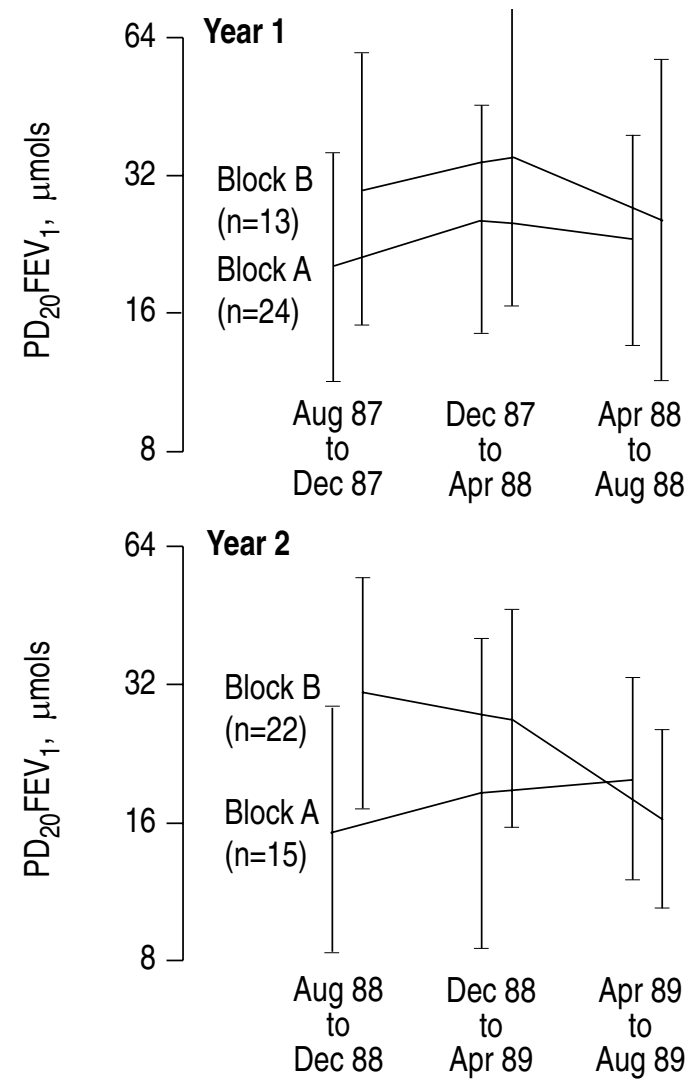

Fig. 4. - Variability of $\mathrm{PD}_{20} \mathrm{FEV}_{1}$ with time period. There was a trend toward an increase in bronchial responsiveness (decrease in $\mathrm{PD}_{20} \mathrm{FEV}_{1}$ ) in Block B (June-August) of each year. Significance: $\mathrm{p}=0.07$, year 2 (repeated measures analysis of variance). Data are presented as mean $\pm 95 \%$ confidence interval. For abbreviations see legend to figure 2 . 
Year 1
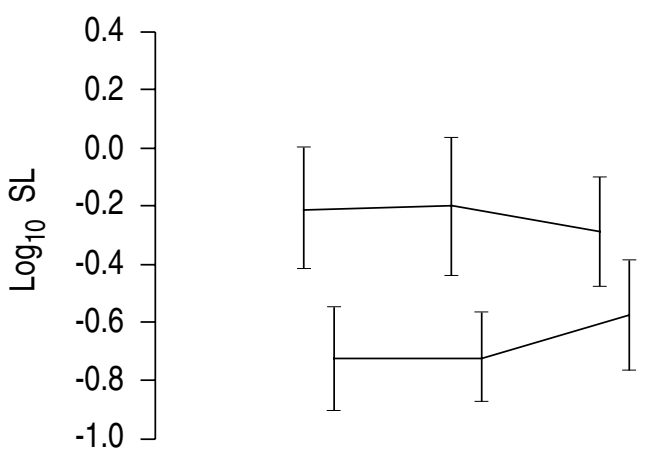

Block A

$(n=34)$

Block B

$(n=38)$
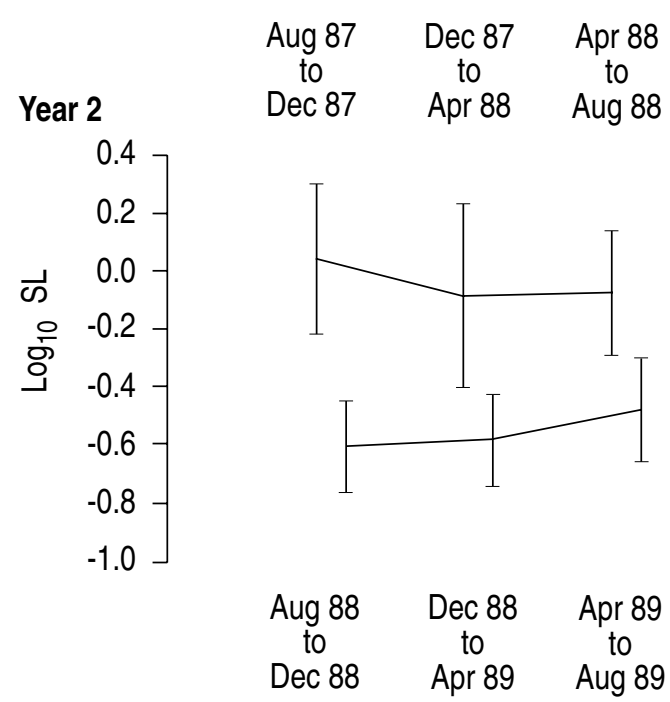

Fig. 5. - Variability of $\log _{10}$ SL with time period (effect of 2 month block of study). There was a trend towards increasing bronchial responsiveness (increase in SL) in Block B (June-August) of each year, which reached significance $(\mathrm{p}=0.025)$ in year 1 (repeated measures analysis of variance). Data are presented as mean $\pm 95 \%$ confidence interval. For abbreviations see legend to figure 2 .

the second year but not by atopy. In both years, there was a trend towards increased bronchial responsiveness in block B between June-August. This was significant for the first year for SL. The effect of time block in which the subjects were studied (timexblock) is shown for both $\mathrm{PD}_{20} \mathrm{FEV}_{1}$ and $\mathrm{SL}$ in tables 2 and 3. Figures 4 and 5 show the variability of $\mathrm{PD}_{20} \mathrm{FEV}_{1}$ and $\mathrm{SL}$ with season.

\section{Discussion}

In this study, we have shown an increase in bronchial responsiveness in winter months, associated with colds and low $\mathrm{FEV}_{1}$, and a trend towards an increase in bronchial responsiveness in late summer not associated with grass pollen skin-prick test positivity. The association with colds was only present in one winter, suggesting that a specific viral epidemic may have been implicated. Colds were not virologically proven, but they were not associated with rhinitis or atopy, making it unlikely that the subjects were reporting allergic rhinitis as a cold. Cold viruses have previously been shown to increase bronchial responsiveness and are strongly linked with asthma exacerbations [25-27], particularly with rhinoviruses [28, 29] which bind to intercellular adhesion molecule-1 (ICAM-1), a receptor for rhinoviruses and inflammatory cells [30]. Low $\mathrm{FEV}_{1}$ is weakly associated with bronchial hyperresponsiveness [9], increasing the likelihood of variability in response to environmental influences.

BRITTON et al. [15] have also shown increased bronchial responsiveness in summer months. The increase was associated with atopy, but not with grass pollen skinprick test positivity. They were only able to measure $\mathrm{PD}_{20} \mathrm{FEV}_{1}$ up to $4 \mu \mathrm{mol}$ histamine, owing to its adverse effects [16]. This is equivalent to the same dose of methacholine [31]. We measured bronchial responsiveness up to $\mathrm{PD}_{20} \mathrm{FEV}_{1} 247 \mu \mathrm{mol}$ methacholine and calculated SL for all subjects, but our findings on atopy and grass pollen skin-prick test positivity were paradoxical and probably artefactual. This may be because allergen exposure is less relevent to those with minimal bronchial responsiveness. It should be noted that the data of BRITTON et al. [15] were analysed using a one-way ANOVA including different subjects at each time-point: some of the seasonal change may be artefactual. However, they were able to perform tests on all subjects during a single month, rather than 4 months, so that their subjects were exposed to similar environmental influences at the time of study. Our study design had the advantage of collection of data throughout the year by a single observer.

$\mathrm{PD}_{20} \mathrm{FEV}_{1}$ analysis was unsatisfactory because of the large number of individuals with minimal responsiveness. Variability was greater than in laboratory studies, in keeping with the findings in other community surveys [31]. Dose-response slope calculation [19] allowed us to include data on all subjects, but variability was greater than for $\mathrm{PD}_{20} \mathrm{FEV}_{1}$. It is likely that magnification of the technical random error is responsible for some of the variability when a small change in $\mathrm{FEV}_{1}$ is logarithmically transformed. This effect shows in the $95 \%$ range $( \pm 4.52 \mathrm{DS})$ but not the $95 \% \mathrm{CI}$, as the CI has as its denominator the square root of sample size (SL $n=67$; $\mathrm{PD}_{20} \mathrm{FEV}_{1} \mathrm{n}=27$ ). The impaired repeatability of SL accounts for the reduction in significance of some associations of bronchial responsiveness. However, it was possible to confirm that the association with colds and summer months applied to the whole group of subjects and not just those with measurable $\mathrm{PD}_{20} \mathrm{FEV}_{1}$. Additionally, the effect of male gender was identified. This may be explained by seasonal exacerbations of mild airflow limitation experienced by smoking males.

In longitudinal studies of bronchial responsiveness, the variability of the test may lead to difficulty detecting the signal from the noise. SL analysis contributes more data on the least responsive tail of the distribution, but its poorer repeatability indicates that it may be best applied in cross-sectional surveys, where a high level of repeatability is not required [32].

In conclusion, we have found seasonal variability of bronchial responsiveness to methacholine in a normal population sample. Bronchial responsiveness increased in summer months. We were not able to identify any significant associations of this seasonal variability. There 
was, however, an increase in bronchial responsiveness in winter months in subjects with colds, but only in the first winter of the study. There was also an effect of low $\mathrm{FEV}_{1}$ at this time, and of male gender during the second winter of the study. Both $\mathrm{PD}_{20} \mathrm{FEV}_{1}$ and SL were poorly repeatable, owing to the high technical random variability of the test and the large number of normal individuals with minimal bronchial responsiveness in the sample.

Acknowledgements: CJT was supported by a grant from the British Lung Foundation. The authors are grateful to the patients of the Canbury Medical Centre for their time and co-operation over the prolonged period of this study.

\section{References}

1. Curry J. The action of histamine on the respiratory tract in normal and asthmatic subjects. J Clin Invest 1946; 25: 785-791.

2. Tiffeneau R. Hypersensibilite cholinergo-histaminique pulmonaire de l'asthmatique. Acta Allergol 1958; (Suppl. 5): 187-221.

3. Cockcroft DW, Killian DN, Mellon JJA, Hargreave FE. Bronchial reactivity to inhaled histamine: a method and clinical survey. Clin Allergy 1977; 7: 235-243.

4. Ramsdell JW, Nachtwey FJ, Moser KM. Bronchial hyperreactivity in chronic obstructive bronchitis. Am Rev Respir Dis 1982; 126: 829-832.

5. Empey DW, Laitinen LA, Jacobs L, Gold WM, Nadel JA. Mechanisms of bronchial hyperreactivity in normal subjects after upper respiratory tract infections. Am Rev Respir Dis 1976; 113: 131-139.

6. Casale TB, Rhodes BJ, Donnelly AL, Weiler JM. Methacholine airway responsiveness in young asymptomatic smokers. J Appl Physiol 1987; 62: 1888-1892.

7. Hopp RJ, Bewtra AK, Watt GD, Nair N, Townley RG. Genetic analysis of allergic disease in twins. J Allergy Clin Immunol 1984; 73: 265-270.

8. Cockcroft DW, Berscheid BA, Murdock KY. Unimodal distribution of bronchial responsiveness to inhaled histamine in a random human population. Chest 1983; 83: 751-754.

9. Trigg CJ, Bennett JB, Tooley M, Sibbald B, D'Souza MF, Davies RJ. A general practice based survey of bronchial hyperresponsiveness and it's relation to symptoms, sex, age, atopy and smoking. Thorax 1990; 45: 866-872.

10. Buist AS, Vollmer WM. Prospective investigations in asthma. What have we learned from longitudinal studies about lung growth and senescence in asthma. Chest 1987; 91 (Suppl.); 119-126S.

11. Clough JB, Williams JD, Holgate ST. Effect of atopy on the natural history of symptoms, peak expiratory flow and bronchial responsiveness in 7 and 8 year old children with cough and wheeze. Am Rev Respir Dis 1991; 143: 755-760.

12. Peat JK, Woolcock AJ, Cullen K. Rate of decline of lung function in subjects with asthma. Eur J Respir Dis 1987; 70: 171-179.

13. Postma DS, De Vries K, Koeter GH, Sluiter HJ. Independent influence of reversibility of airflow obstruction and nonspecific hyperreactivity on the long-term course of lung function in chronic airflow obstruction. Am Rev Respir Dis 1986; 134: 276-280.
14. Parker DR, O'Connor GT, Sparrow D, Segal MR, Weiss ST. The relationship of nonspecific airway responsiveness and atopy to the rate of decline of lung function. Am Rev Respir Dis 1990; 141: 589-594.

15. Britton J, Chinn S, Burney P, Papacosta AO, Tattersfield A. Seasonal variation in bronchial reactivity in a community population. J Allergy Clin Immunol 1988; 82: 134 139.

16. Juniper EF, Frith PA, Dunnett C, Cockcroft DW, Hargreave FE. Reproducibility and comparison of responses to inhaled histamine and methacholine. Thorax 1978; 33: 705-710.

17. Bennett JB, Davies RJ. A comparison of histamine and methacholine bronchial challenges using the DeVilbiss 646 nebulizer and the Rosenthal-French dosimeter. $\mathrm{Br} \mathrm{J}$ Dis Chest 1987; 81: 252-259.

18. Cotes J. In: Lung Function. Oxford, Blackwell Scientific Publications. 1979; pp. 329-387.

19. O'Connor G, Sparrow D, Taylor D, Segal M, Weiss S. Analysis of dose-response curves to methacholine. Am Rev Respir Dis 1987; 136: 1412-1417.

20. Bennett JB, Osman J, Blainey AD, Davies RJ. The assessment of a computer administered questionnaire in the differential diagnosis of asthma and chronic airflow limitation. Br J Dis Chest 1988; 82: 268-273.

21. Armitage P, Berry G. In: Statistical methods in medical research. Oxford, Blackwell Scientific Publications. 1987; pp. 186-193 and 214-222.

22. Snedecor GW, Cochran WG. In: Statistical Methods. Iowa State University Press, 1980; pp. 243-245.

23. Armitage P, Berry G. In: Statistical Methods in Medical Research. Oxford, Blackwell Scientific Publishers. 1987; 296-312.

24. SAS/STAT user guide. Cary, North Carolina, USA, 1990; pp. 223-226.

25. Lemanske RF, Dick EC, Swenson CA, Vrtis RF, Busse WW. Rhinovirus upper respiratory tract infection increases airway hyperreactivity and late asthmatic reactions. $J$ Clin Invest 1989; 83: 1-10.

26. Beasley R, Coleman ED, Hermon Y, Holst PE, O'Donnell TV, Tobias M. Viral respiratory tract infections and exacerbations of asthma in adult patients. Thorax 1988; 43: 679-683.

27. Horn MEC, Brain EA, Gregg I, Inglis JM, Yealland SJ, Taylor P. Respiratory viral infections and wheezy bronchitis in childhood. Thorax 1979; 34: 23-28.

28. Johnston SL, Sanderson G, Pattemore PK, et al. Use of the polymerase chain reaction for diagnosis of picornavirus infection in subjects with and without respiratory symptoms. J Clin Microbiol 1993; 31: 111-145.

29. Ireland D, Kent J, Nicholson KG. Improved detection of rhinoviruses in nasal and throat swabs by semi-nested RT-PCR. J Med Virol 1993; 40: 96-101.

30. Springer T. Adhesion receptors of the immune system. Nature 1990: 346: 425-434.

31. Higgins BG, Britton JR, Jones TD, Vathenen AS, Burney PGJ, Tattersfield AE. Comparison of histamine and methacholine for use in bronchial challenge tests in community studies. Thorax 1988; 43: 605-610.

32. Bruschi C, Cerveri I, Zoia MC, Maccarini L, Grassi M, Rampulla C. Bronchial responsiveness to inhaled methacholine in epidemiological studies: comparison of different indices. Eur Respir J 1989; 2: 630-636. 